\title{
UTILIZATION OF MILLING MACHINE FOR SEPARATING GRASS SEEDS FROM ALFALFA SEEDS
}

\author{
EL-Sayed, G. $H^{*}$.; Shreen, F. A. $M^{* * *}$. and Y. A. Shabaan ${ }^{* * *}$
}

ABSTRACT

The purpose of this study was to increase the efficiency of rice milling machine, by using it as a multipurpose machine (milling - separation). The rice milling machine was used for separating grass seeds (Chicory and Clover Dodder) from alfalfa seeds under four treatment feed rates of $250,300,350$ and $400 \mathrm{~kg} / \mathrm{h}$, three seed moisture contents of 8, 10 and $12 \%$, four speeds of cleaning air of 4.0, 6.0, 8.0 and $10.0 \mathrm{~m} / \mathrm{s}$ and four sieve oscillates speed of 200, 230, 260 and $290 \mathrm{rpm}$. Those treatments were evaluated by determination of seeds losses and damage, purity percentage, energy and production cost. The results show that, the lowest value of seed losses of 2.0, 3.0 and $8.0 \%$ were obtained at air speeds of 4, 6 and $8 \mathrm{~m} / \mathrm{s}$ and feed rate of $250 \mathrm{~kg} / \mathrm{h}$ and the lowest value of seeds damage was noticed at air speeds of $4 \mathrm{~m} / \mathrm{s}$, moisture contents of 8 and $10 \%$ and feed rate of 250 $\mathrm{kg} / \mathrm{h}$. Too, the maximum value of seeds purity of 98, 98.2, 98.3 and $98.5 \%$ was obtained used feed rate of $250 \mathrm{~kg} / \mathrm{h}$, sieve oscillations of 200, 230, 260 and $290 \mathrm{rpm}$ and air speeds of $6 \mathrm{~m} / \mathrm{s}$ and moisture content of $10 \%$. The maximum value of machine efficiency was obtained under used sieves oscillation of $200 \mathrm{rpm}$ with feed rate of $250 \mathrm{~kg} / \mathrm{h}$ and cleaning air speed of 4 and $8 \mathrm{~m} / \mathrm{s}$ While the minimum energy consumed of $4.5 \mathrm{~kW} /$ ton was obtained by using cleaning air speed of $4 \mathrm{~m} / \mathrm{s}$ and sieve oscillation of $200 \mathrm{rpm}$. The lowest cost of 265.4 LE/ton was recorded under parameter of air speed of 4and $6 \mathrm{~m} / \mathrm{s}$, sieve oscillation of $200 \mathrm{rpm}$ and feed rate of $250 \mathrm{~kg} / \mathrm{h}$.

\section{INTRODUCTION}

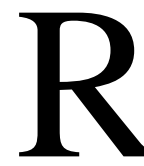

ice milling machines are rife in Egypt because, rice is one of the most important crops in Egypt and its production role a milling machines character rise by ease of replacement of any part of the milling machine and easily control the direction and speed of the air, making it easier to use in the process of separating the grass seeds from alfalfa seeds.

\footnotetext{
* Head Researcher, Agric. Eng. Res. Institute, Agric. Res. Center, Dokki, Egypt.

** Senior Researcher, Agric. Eng. Res. Institute, Agric. Res. Center, Dokki, Egypt.

*** Researcher, Agric. Eng. Res. Institute, Agric. Res. Center, Dokki, Egypt.
} 
Amin (2003) said that the sieving time, cell shape, and oscillating speed were the main factors that affected the separation efficiency. This efficiency increased by increasing sieving times and oscillating speed rpm. Mehdi et al (2007) study some physical properties of raw paddy (var. Sazandegi) are discussed briefly. At moisture content of $10 \%$ (wet basis), the average seed length, width and thickness were 8.54, 2.47 and $1.83 \mathrm{~mm}$, respectively while the equivalent mean diameter, surface area and volume were $3.4 \mathrm{~mm}, 32.58 \mathrm{~mm}^{2}$ and $21.06 \mathrm{~mm}^{-3}$, respectively. The sphericity and aspect ratio were 39.88 and $0.29 \%$, respectively. True density, bulk density and porosity were $1193.38 \mathrm{~kg} \mathrm{~m}^{-3}, 471.16 \mathrm{~kg} \mathrm{~m}^{-3}$ and $60.37 \%$, respectively while the static coefficient of friction varied from 0.2186 on glass sheet to 0.4279 on plywood. The angle of repose for emptying was 35.83o. The physical properties of paddy and rice, like those of other seeds and seeds, are necessary for design of equipment for handling, harvesting, processing and storing the seed or determining the behavior of the product for its handling (Baryeh and Mangope, 2002). Werby (2010) studied some physical and mechanical properties of alfalfa seeds, the results showed that cell shape, sieve tilt angle, sieve oscillation and air speed are the main factors that affect purity and total losses in cleaning. The purity increased by increasing air speed, sieve tilt angle and sieve oscillation. Total losses increased by increased air speed, sieve tilt angle and oscillation. The optimum performance of $98 \%$ was at air speed of $6 \mathrm{~m} / \mathrm{s}$, moisture content of $10.5 \%$, sieve oscillation of $250 \mathrm{rpm}$, sieve tilt angle of 35, round shaped sieve $4 \mathrm{~mm}$ diameter, and feed rate of 500 $\mathrm{kg} / \mathrm{h}$. purity at these conditions was $99 \%$ and total losses $1 \%$. Also, they stated that the studied physical and mechanical properties of three different varieties of clover seeds: Length, and width, for AL-Mesqawi, AL-Khadrawi and Al-Seadi were 2.40, and 2.10; 2.45and $2.12 ; 3.00$ and $2.10 \mathrm{~mm}$ respectively. Percent of sphericity and Volume for ALMesqawi, AL-Khadrawi and Al-Seadi were 87, 86 and $70 \%$; 4.55, 4.65, and $5.36 \mathrm{~mm}^{3}$ respectively. Terminal velocities for AL-Mesqawi, ALKhadrawi and Al-Seadi were, 15,15 and $16 \mathrm{~m} / \mathrm{s}$ respectively. Shreen and Khaffaf (2015) measured physical and mechanical properties of Clover Dodder: length of $0.65 \mathrm{~mm}$, width of $0.60 \mathrm{~mm}$ and thickness of $0.62 \mathrm{~mm}$ respectively, volume $0.13 \mathrm{~mm}^{3}$, geometric diameter $0.62 \mathrm{~mm}$, 
arithmetic diameter $0.62 \mathrm{~mm}$, percentage of sphericity $95.84 \%$, bulk density $0.019 \mathrm{~kg} / \mathrm{m}^{3}$, flat surface area $0.31 \mathrm{~mm}^{2}$ transverse surface area $0.29 \mathrm{~mm}^{2}$ mass of 1000 -seeds $2.5 \mathrm{~g}$ and moisture content of $9.5 \%$. And for Chicory seeds, the Physical properties: length, width , and thickness were 2.25, 0.60 , and $1.12 \mathrm{~mm}$ respectively, volume $0.88 \mathrm{~mm}^{3}$, geometric diameter 1.19 $\mathrm{mm}$, arithmetic diameter $1.35 \mathrm{~mm}$, percentage of sphericity $52.92 \%$, bulk density $0.006 \mathrm{~g} / \mathrm{mm}^{3}$,flat surface area $1.97 \mathrm{~mm}^{2}$ transverse surface area 0.59 $\mathrm{mm}^{2}$ mass of 1000 -seeds $5.0 \mathrm{~g}$ and optimum moisture content of $9.0 \%$. They found that the terminal velocity value to suspend Clover Dodder seed was $2 \mathrm{~m} / \mathrm{s}$ and hardness was $14.20 \mathrm{~N}$ and for Chicory seeds was $3 \mathrm{~m} / \mathrm{s}$. and hardness was $4.17 \mathrm{~N}$, as well this research work targets in modify rice milling machine. This study aims to modify the milling rice machine to use as a multipurpose machine (milling - separation) for increasing the efficiency.

\section{MATERIALS AND METHODS}

To fulfill the objective of this study, two tons of alfalfa seeds were used to separate grass seeds (Clover Dodder and Chicory) from alfalfa seeds by using modified milling rice machine. The experimental work was carried out at a private machine in Owlad Sakr District, Sharkia Governorate Egypt during 2016 summer season.

\section{The milling machine specification:}

Fig.1. shows the ingredients milling machine used to separate grass seeds (Clover Dodder and Chicory) from alfalfa seeds. The type of machine is Mn 80 made in china, motor power of $11 \mathrm{~kW}$ and weight of $150 \mathrm{~kg}$. The parts specification of this machine which was used in separating process was:

\section{Modify sieves:}

The two oscillating sieves are pre-cleaner, simple and made from locally material. Sieves have different sizes depending on the size and shape of the tested seeds. The top sieve of dimensions (16 hole/mish and $\phi 5 \mathrm{~mm}$ ) and the shape circular has a slotted profile larger than the bottom one and both screens can be changed to suit the seed size or crop type. Seeds flow onto the oscillating sieve to separate large impurities such as chaff and straw. 


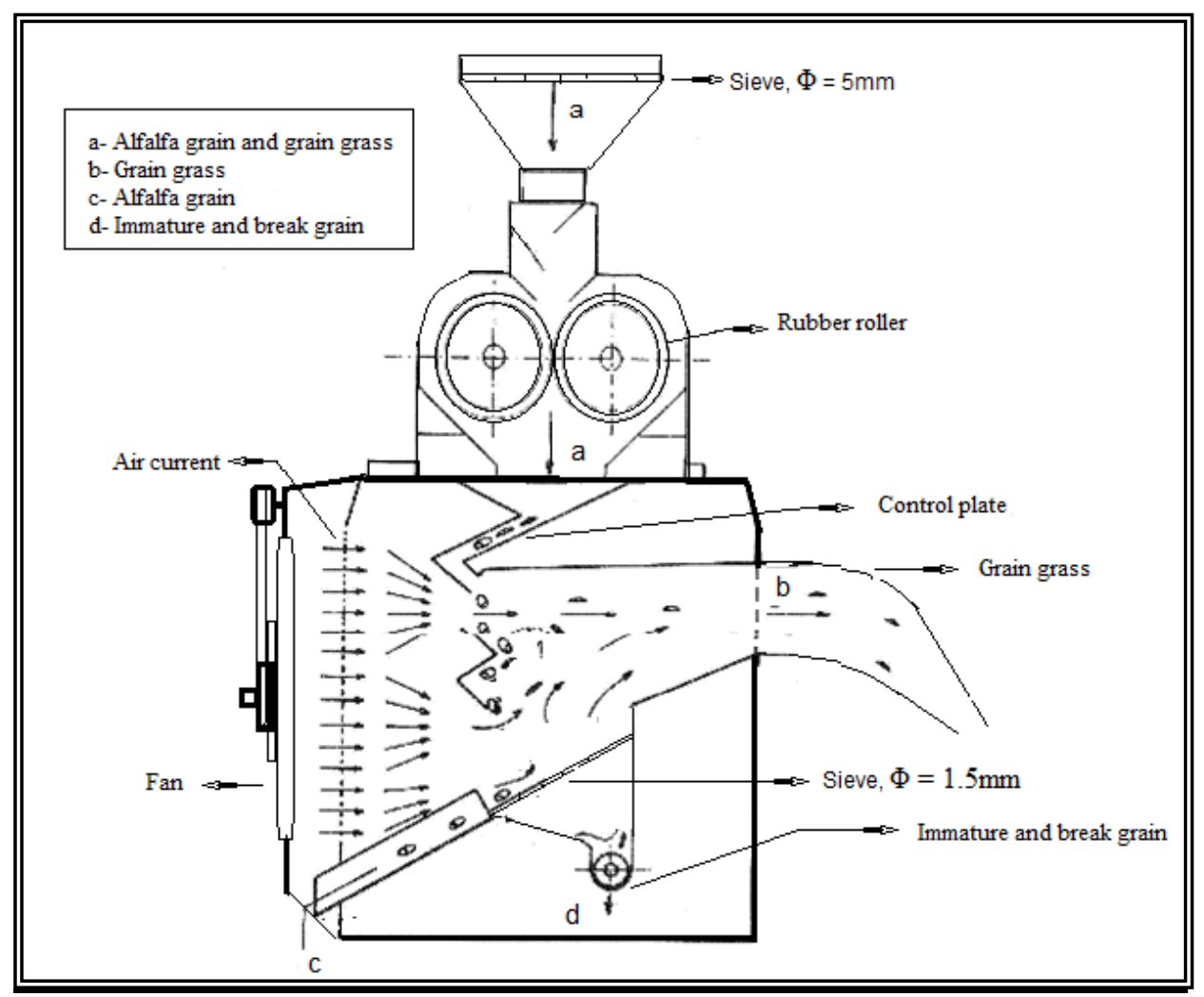

Fig. 1: Sketch view of the milling machine.

The feed rates which were used in this experiment were 250, 300, 350 and $400 \mathrm{~kg} / \mathrm{h}$. The bottom sieve oscillated for removing lighter impurities such as dust and dirt, by both of blowing or sucking air through the mass of falling seed through the opening of oscillating sieves. The sieving action of this machine is similar to top sieve oscillation cleaner. The measurement of hole diameter was $1.5 \mathrm{~mm}$ and tilled at angle of 3 degree and the range of sieve oscillations was 200, 230, 260 and $290 \mathrm{rpm}$.

Rubber roller huller: The rubber-roller huller consists of two rubber rollers of the same diameter operated at different speeds. One roller has a fixed position and the other is adjustable to meet the desired clearance. Rubber-roll hullers have an aspirator in the base, the roll diameter of 150 $\mathrm{mm}$ and the roll width of $60 \mathrm{~mm}$. The correct clearance is dependent on the varietals characteristics and the width and length of seed. So, this 
experiment used three different clearances between the two drums (5, 7, 9 and $11 \mathrm{~mm}$ ) to control the amount of seeds which pass through them. The minimum clearance between two rolls was of $5 \mathrm{~mm}$ which was allowed the seed to pass without damage because this dimension was less than the maximum length of seed; these clearances were used to regular the amount seeds which flow in unit time and control the feed rate. Whereas the clearance between the two drums was $5,7,9$ and $11 \mathrm{~mm}$ the seeds amount which pass in hour were $250,300,350$ and $400 \mathrm{~kg}$ respectively.

Blower: The blower is made of metal sheet of $1 \mathrm{~mm}$ thickness. The blower fan assembly consists of six bladed radial fans, driver from electric motor with V-shape pelt bully. The fan discharges air blast through the sieve perforations.

\section{Measuring instrumentation:}

Electrical balance: An electronic balance was used for weighing samples before and after cleaning. Its scale ranged from 0 to $5 \mathrm{~kg}$ max., with accuracy of $0.2 \mathrm{~g}$.

Anemometer instrument: An anemometer instrument (SATAKE CO., Japan) was used for measuring the air speed. It is ranged from 0 to 50 $\mathrm{m} / \mathrm{s}$. The measurement theory depends on the declination of the sensor inside the instrument.

Moisture content meter: Moisture content of alfalfa seeds was determined by using as electronic moisture meter. Its specifications were as following: Type: GANN Hydromelle G 86, Made in Western Germany.

\section{Measurements:}

\section{The alfalfa seed damaged.}

Random seed samples each of five kilograms were collected from the product of each treatment. Each sample was divided manually into ten equal parts. Each part was divided into five small parts each of about $100 \mathrm{~g}$. Each sample of $100 \mathrm{~g}$ has been distributed on a flat glass plate to sort the product into three main categories namely broken and injured seeds (seeds damaged) 
Then, the percent of each component could be estimated as follows: Seeds damaged, $\%=\frac{(B+I)}{T} \times 100$

Where:-

$\mathrm{B}=$ Mass of broken seeds, $\mathrm{g} ; \mathrm{I}=$ Mass of injured seed, $\mathrm{g}$ and $\mathrm{T}=$ Total mass of sample, $\mathrm{g}$.

\section{Alfalfa seed losses.}

The alfalfa seed losses were determined by taking random samples from sieves and air current product. Sample by mass $1 \mathrm{~kg}$ was taken and divided into five samples and the number of alfalfa seeds in each sample was determined. The following items are determined by using equation

Total seeds losses $=\frac{W_{d}+W_{u}}{W_{t}} \times 100, \%$.

Where:-

$W_{d}$ is mass of alfalfa seeds in sieve product, $\mathrm{g}$.

$W_{u}$ is mass of alfalfa seeds in air current product, g. and

$W_{t}$ is mass of total input seeds, $\mathrm{g}$.

Machine performance:

The following items are determined as cited by Srivastava et al. (2006): Actual machine capacity (AC):

$$
A C=\frac{1}{A T}, \text { ton } / \mathrm{h}
$$

Where:

AT is actual total time required for cleaning one ton of alfalfa seed, $h$.

Machine productivity $=\frac{\mathrm{W}_{\mathrm{c}}}{A T}$, ton seeds $/ \mathrm{h}$

Where; $\mathrm{W}_{\mathrm{c}}$ is mass of clean seeds, ton $/ \mathrm{h}$.

\section{Machine efficiency $(\eta f)$ :}

$\eta_{f}=\frac{\mathrm{AC}}{\mathrm{TC}} \times 100, \%$

Where:

$A C$ is the actual machine capacity, ton $/ \mathrm{h}$

$T C$ is theoretical machine capacity, ton/h. 


\section{Specific energy consumption:}

To compute the energy consumption, similar electrometers model (CA4N672T) has been used to measure the electrical energy consumption; this value was added to specific human energy consumption.

\section{Specific laborer energy requirements:}

The following items were determined as cited by Srivastava et al. (2006):

Laborer energy requirements $=3.61 x 0.075 x A F C^{h} x N l, \mathrm{~kJ}$

Where:

0.075 is power of laborer, $\mathrm{kW} / \mathrm{h}$.

$\mathrm{Nl}$ is number of laborers.

$A F C^{h}$ is manual capacity, $0.2 \mathrm{Ton} / \mathrm{h}$.

Total energy requirements $=$ account the electrical + human energy

Ouput energy requirements $=\frac{\text { Total } \text { energy requirements }}{\text { Machine productivity }}, \mathrm{kW} / \mathrm{ton}$

\section{Costs:}

As cited by Begum et al. (2012), separation costs (LE/h) are calculated by employing the conventional method of estimating both fixed and variable costs.

Separation criterion costs $=\frac{\text { operational } \operatorname{costs}(\mathrm{LE} / \mathrm{h})}{\text { Machine } \text { productivity }}+$ lossed grains price, $\mathrm{LE} / \mathrm{ton}$

\section{Factor relating to the constructed separating machine:}

The following factors were tested to show their effect on separation effectiveness:

1- Feed rate: $250,300,350$ and $400 \mathrm{~kg} / \mathrm{h}$.

2 -Air speed: 4, 6, 8 and $10 \mathrm{~m} / \mathrm{s}$.

3 - Sieve oscillations: 200, 230, 260 and $290 \mathrm{rpm}$.

4 - Moisture content: 8, 10 and $12 \%$.

5 - Sieve tilt-angle: 3degree.

Data analysis: complete randomized block design is selected to study the effect of seed moisture content, feeding rate, sieving oscillating, and air speed as dependent variables as a function of alfalfa seed losses, seed damage and purity as independent variable. These relationships are tested 
by using an analysis of variance and predicting the change of dependent variables by using SPSS version-20.0 (SPSS, Inc., Chicago, IL, USA).

\section{RESULTS AND DISCUTION}

Effect of cleaning air speed, moisture content and feed rate on seed losses:

The obtained result illustrated that by increasing cleaning air speed the seed losses are increased under treatment tested feed rates. So, by using feed rate of $250 \mathrm{~kg} / \mathrm{h}$ the seed losses are increased by average of $1.4 \%$ under used air speeds of 4, 8, 10 and $12 \mathrm{~m} / \mathrm{s}$. The minimum value of seed losses of $2.0 \%$ was noticed under used feed rate of $400 \mathrm{~kg} / \mathrm{h}$, moisture content of $12 \%$ and air speed of $4 \mathrm{~m} / \mathrm{s}$ and the maximum value of $5.3 \%$ was noticed by using feed rate of $250 \mathrm{~kg} / \mathrm{h}$, moisture content of $8 \%$ and air speed of $8 \mathrm{~m} / \mathrm{s}$. Furthermore, when moisture content was increased by average of $2 \%$ the seed losses are decreased by average of $1.2 \%$ under stable feed rate and air speed. Increased losses are due to increase of air quantity and decreased feed rate therefore a low number of seeds were exposed to high quantity of air so, pushing more seeds. Above mentioned results suggested that the lowest values of seed losses of 2.0, 3.0 and 8.0 $\%$ were obtained at air speed of 4,6 and $8 \mathrm{~m} / \mathrm{s}$, feed rate of $250 \mathrm{~kg} / \mathrm{h}$ and moisture content $10 \%$. But, by increasing moisture content of $2 \%$ the seed losses were decreased by average of $0.4 \%$. These data was shown in Fig.2. Furthermore, by analyzing the results statistically and determine the value of the correlation coefficient, it was found to be equal to 0.80 this shows that there is effect of air speed, moisture content and feed rate on seeds losses and this relationship is a positive.

\section{Effect of air speed, moisture content and feed rate on seeds damage:}

Under stable sieves oscillations, the data in Fig. 3 show that by increasing air speed by $2 \mathrm{~m} / \mathrm{s}$ the seeds damage was increased by average of $1.5 \%$. Too, by increasing feed rate by $50 \mathrm{~kg} / \mathrm{h}$ the seeds damage was increased by average of $2.3 \%$. The minimum value of seeds damage 1.5 and $2.0 \%$ was noticed under feed rate of $250 \mathrm{~kg} / \mathrm{h}$, moisture content of 8 and $10 \%$ air speed of $4 \mathrm{~m} / \mathrm{s}$ and the maximum value of $6.4 \%$ was noticed under used feed rate of $400 \mathrm{~kg} / \mathrm{h}$, moisture content of $12 \%$ and air speed of 10 $\mathrm{m} / \mathrm{s}$. Furthermore, when moisture content was increased by average of 2 $\%$ the seeds damage was increased by average of $1.4 \%$ under stable feed 
rate and air speed. Increased in seeds damage were due to increase of feed rate therefore the high number of seeds which try to pass between two roll so, the seeds were exposed to compress. Furthermore, by analyzing the results statistically and determine the value of the correlation coefficient, it was found to be equal to 0.63 this shows that there is mean effect of air speed, moisture content and feed rate on seeds damaged and this relationship is a positive.

\section{Effect of air speed, moisture content and feed rate on seeds purity:} Under stable sieves oscillations, the data in Fig .4 show that by increasing air speed by $2 \%$ the seeds purity was increased by average of $4.5 \%$. Too, by increasing feed rate by $50 \mathrm{~kg} / \mathrm{h}$ the seeds purity was decreased by average of $2.5 \%$. The minimum value of seeds purity of $89 \%$ was noticed under feed rate of $400 \mathrm{~kg} / \mathrm{h}$, moisture content of $12 \%$ and air speed of $4 \mathrm{~m} / \mathrm{s}$ and the maximum value of seeds purity of $98 \%$ was noticed under used feed rate of $250 \mathrm{~kg} / \mathrm{h}$, moisture content of $10 \%$ and air speed of 6,8 and $10 \mathrm{~m} / \mathrm{s}$ (there are no significant between the values of seeds purity by using air speed of 6,8 and $10 \mathrm{~m} / \mathrm{s}$ ) because, seed movement's ability to be less by increasing moisture content. Furthermore, when moisture content was increased by average of $2 \%$ the seeds purity was decreased by average of $1.15 \%$ under stable feed rate and air speed. Increased in seeds purity were due to increase of air quantity and decreased feed rate therefore the low number of seeds exposed the high quantity of air so, more than in seeds purity. Above mentioned results suggested that the highest values of seeds purity were noticed at air speed 6,8 and $10 \mathrm{~m} / \mathrm{s}$ and moisture content 8 and $10 \%$ and feed rate $250 \mathrm{~kg} / \mathrm{h}$. The grasses seeds were removed by using air current which comes from cleaning fan. The alfalfa seeds work by making use of differences in specific gravity, buoyancy and size between alfalfa seed and grasses seeds. Grass seed has a lower specific gravity and higher buoyancy than alfalfa seeds. Furthermore, by analyzing the results statistically and determine the value of the correlation coefficient, it was found to be equal to 0.46 this shows that there is medium effect of air speed, moisture content and feed rate on seeds purity and this relationship is a positive. 


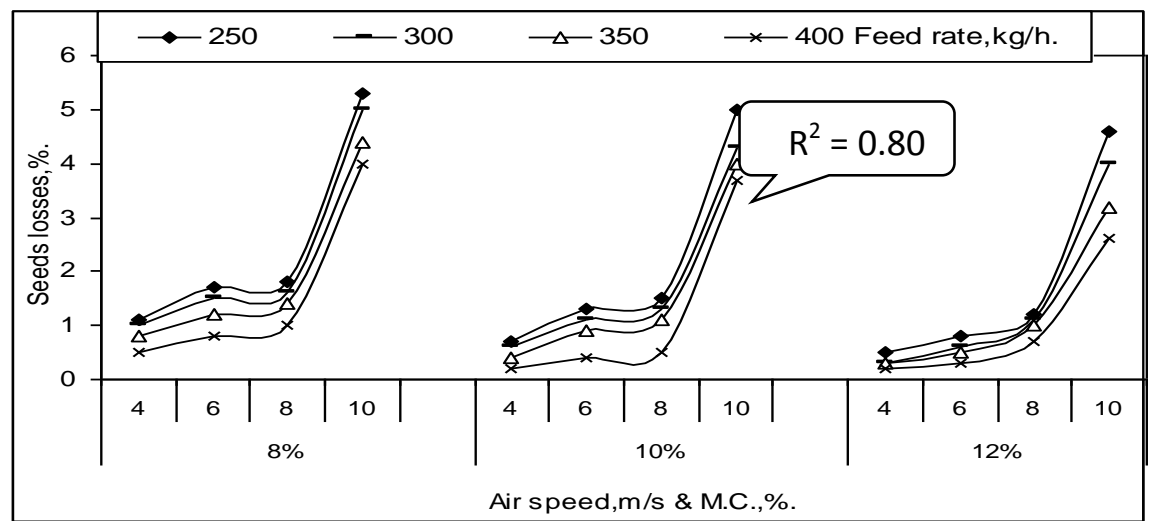

Fig. 2: The effect of air speed, moisture content and feed rate on seed losses.

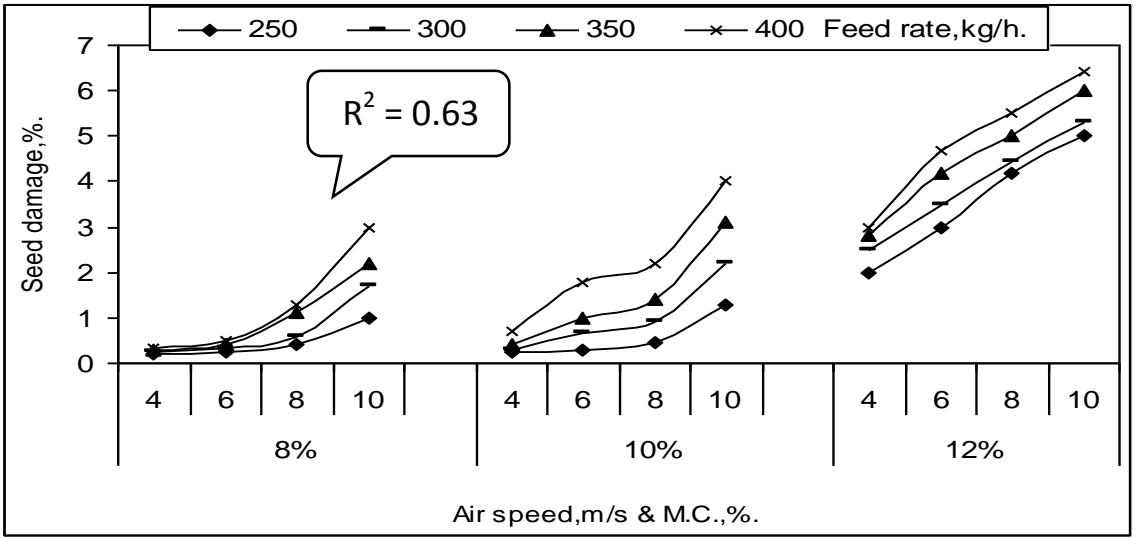

Fig. 3: The effect of air speed, moisture content and feed rate on damaged seeds.

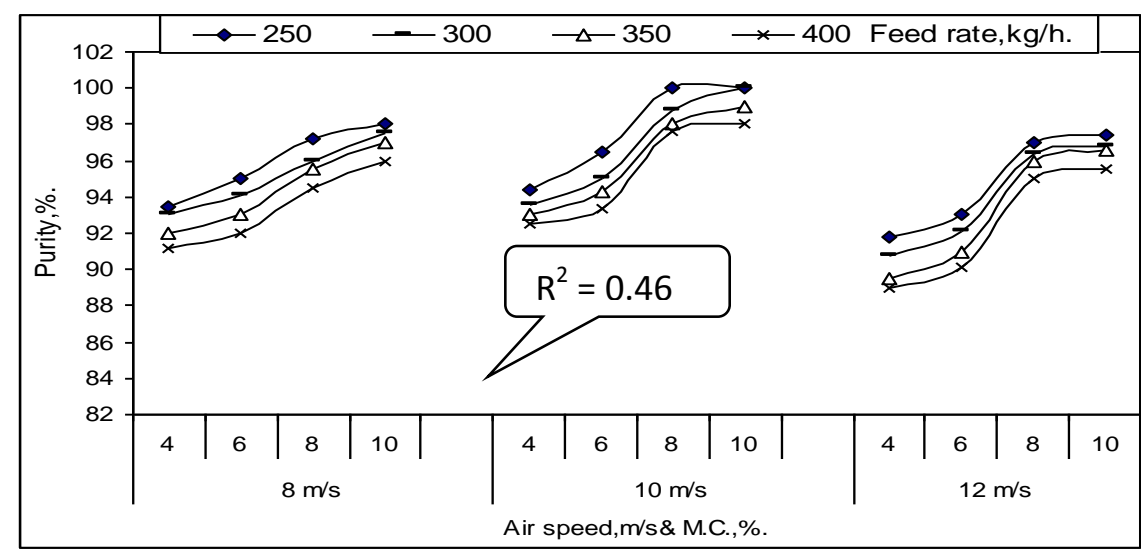

Fig.4: Effect of air speed, seed moisture content and feed rate on seeds purity. 


\section{Effect of air speed, sieve oscillations and feed rate on seeds purity:}

Through previous results showing that the best moisture content for separate was $10 \%$. And the optimum sieve tilt-angle of 3degree (Werby2013) .The data in Fig. 5 shown that by increasing air speed the seeds purity was increased by average of $6.6 \%$. Too, by increasing feed rate the seeds purity was decreased by average of $13.7 \%$. The minimum value of seeds purity of $85 \%$ was noticed under used feed rate of $400 \mathrm{~kg} / \mathrm{h}$, sieve oscillations of $200 \mathrm{rpm}$ and air speed of $4 \mathrm{~m} / \mathrm{s}$ and the maximum value of seeds purity of $98.1,98.2,98.3$ and $98.4 \%$ was noticed under used feed rate of $250 \mathrm{~kg} / \mathrm{h}$, sieve oscillations of 200,230 , 260 and $290 \mathrm{rpm}$ and air speeds and there was no significant value between used air speed 6 and $10 \mathrm{~m} / \mathrm{s}$. This was due to the alfalfa and grass seeds move over an inclined plane, they move at different speeds depending on their specific gravity, their shape and contact area, smoothness of inclined surface and the co-efficient of sliding friction. Alfalfa seeds are bigger, heavier, rounder and smoother and will slide faster than grass seeds. Furthermore, when a sieve oscillation was increased by $30 \mathrm{rpm}$ the seeds purity was increased by average of $0.2 \%$ under stable feed rate and air speed. The increase in seeds purity was due to increase of movement of material fast on the sieve giving less chance for straw and impurities to pass through the seed spout. The above mentioned results suggested that the highest values of seeds purity were noticed at air speeds of $6 \mathrm{~m} / \mathrm{s}$ and sieve oscillations of $200 \mathrm{rpm}$ and feed rate of $250 \mathrm{~kg} / \mathrm{h}$. Furthermore, by analyzing the results statistically and determine the value of the correlation coefficient, it was found to be equal to 0.92 this shows that there is a strong effect of air speed, sieve oscillations and feed rate on seeds purity and this relationship is a positive.

\section{Effect of air speed, sieve oscillations and feed rate on seeds losses:} The previous results showing that the best moisture content for separation was $10 \%$. And the optimum sieve tilt-angle of 3degree (Werby2013). The data in Fig. 6.show that by increasing air speed the seeds loss was 
increased by average of $6.6 \%$. Too, by increasing feed rate the seeds purity was decreased by average of $17.5 \%$.

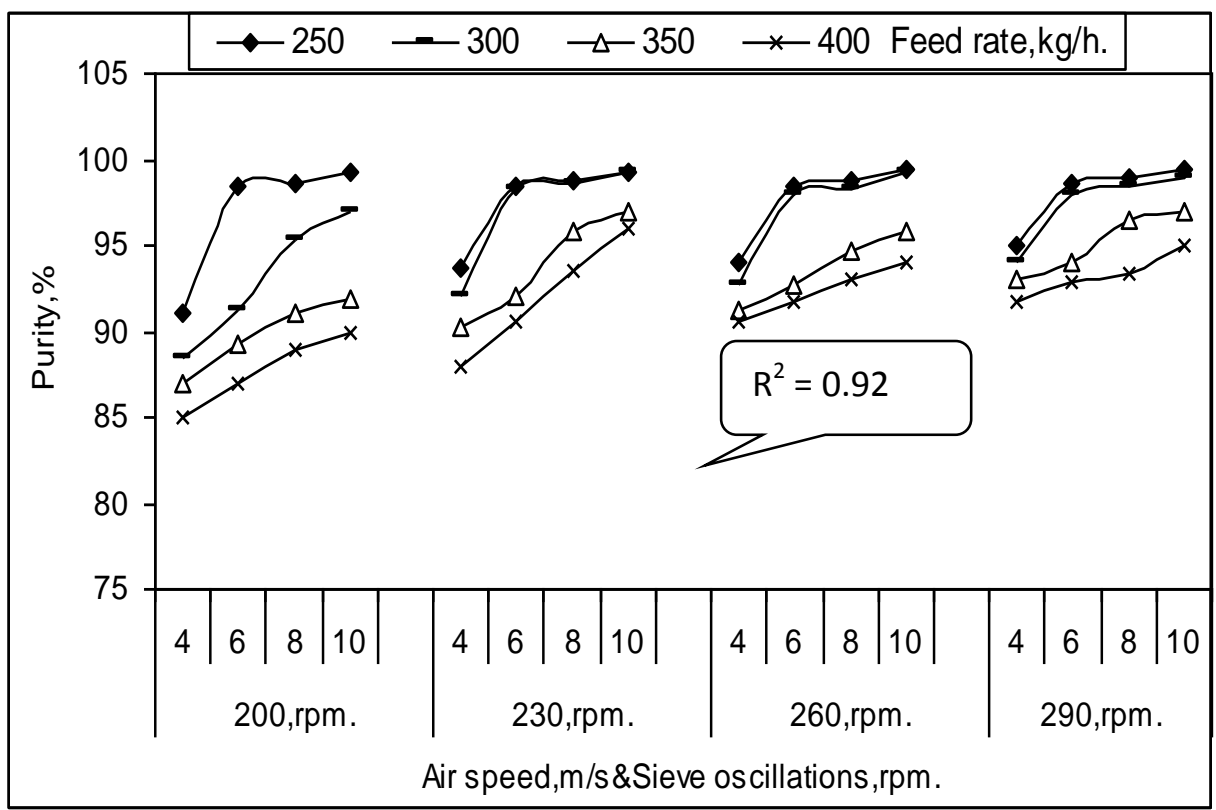

Fig.5: Effect of air speed, sieve oscillations and feed rate on seeds purity.

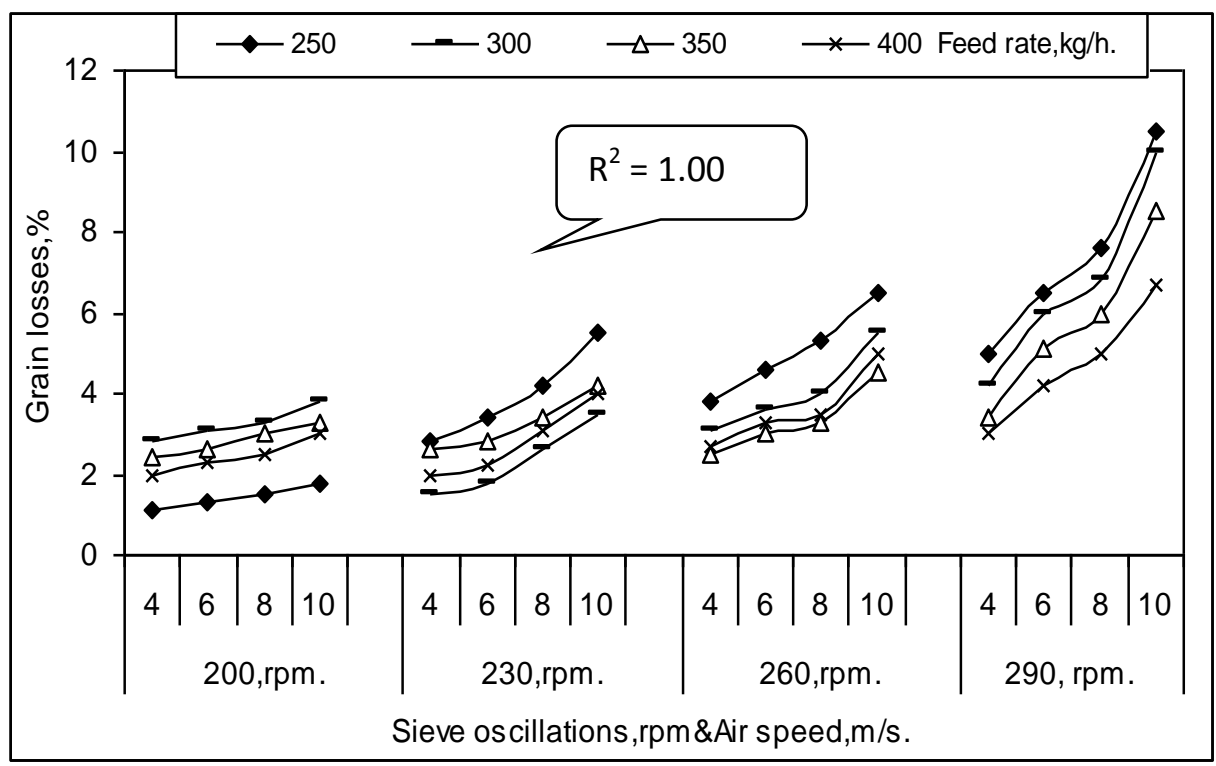

Fig.6: Effect of air speed, sieve oscillations and feed rate on seed losses. 
The minimum value of seeds losses of $1.5 \%$ was noticed under used feed rate of $250 \mathrm{~kg} / \mathrm{h}$, sieve oscillations of 200 rpm and air speed of 4 and $6 \mathrm{~m} / \mathrm{s}$ and the maximum value of seeds losses of $18.5 \%$ was noticed under used feed rate of $250 \mathrm{~kg} / \mathrm{h}$, sieve oscillations of $290 \mathrm{rpm}$ and air speed of 10 $\mathrm{m} / \mathrm{s}$. This was due to, seed movement is gaining kinetic energy as a result of the movement of a sieve and increases with increase the speed of a sieve, which increases the speed of seed, this was due to start the seeds go outside the scope of a sieve, which increases the rate of seed losses and this was due to, the kinetic energy distribution of a smaller quantity of seed so increase its speed and thus increase the rate of seed losses. Furthermore, when a sieve oscillation was increased by average of $30 \mathrm{rpm}$ the seed losses were increased by average of $2.7 \%$ under stable feed rate and air speed. Above mentioned results suggested that the highest values of seed losses were noticed at air speed of $10 \mathrm{~m} / \mathrm{s}$ and sieve oscillation of $290 \mathrm{rpm}$ and feed rate of $250 \mathrm{~kg} / \mathrm{h}$. Furthermore, by analyzing the results statistically and determine the value of the correlation coefficient, it was found to be equal to 0.94 this shows that there is strong effect of air speed, sieve oscillations and feed rate on seeds losses and this relationship is a positive.

\section{Machine efficiency:}

Effect of air speed, sieve oscillations and feed rate on machine efficiency is shown in table 1 . The data in this table illustrated that, the maximum value of machine efficiency was noticed under used sieves oscillation of $200 \mathrm{rpm}$ with feed rate of $250 \mathrm{~kg} / \mathrm{h}$ and cleaning air speed of 4 and $6 \mathrm{~m} / \mathrm{s}$, on the whole, the optimum cleaning air speed of $6 \mathrm{~m} / \mathrm{s}$ was gave the maximum value of machine efficiency under used most treatments.

\section{Effect of cleaning air speed and sieve oscillation on consumed energy:}

Fig. 7 shows that by increasing cleaning air speed, the consumed energy will increase. The maximum consumed energy of $7.5 \mathrm{~kW} /$ ton was obtained by using cleaning air speed of $10 \mathrm{~m} / \mathrm{s}$ and sieve oscillation 290 rpm. While the minimum consumed energy of $4.5 \mathrm{~kW} /$ ton was obtain by using cleaning air speed $4 \mathrm{~m} / \mathrm{s}$ and sieve oscillation $200 \mathrm{rpm}$. 
Table .1: The relation between feed rate, cleaning air speed and sieve oscillation on machine efficiency.

\begin{tabular}{|c|c|c|c|c|c|}
\hline \multirow{3}{*}{$\begin{array}{c}\text { Machine } \\
\text { feeding rate, } \\
\mathrm{kg} / \mathrm{h}\end{array}$} & \multirow{3}{*}{$\begin{array}{c}\text { Cleaning } \\
\text { air speed, } \\
\text { m/s. }\end{array}$} & \multicolumn{4}{|c|}{ Machine efficiency, \%. } \\
\hline & & \multicolumn{4}{|c|}{ Sieve oscillation, rpm. } \\
\hline & & 200 & 230 & 260 & 290 \\
\hline \multirow{4}{*}{250} & 4 & 98.0 & 97.5 & 96.2 & 95.0 \\
\hline & 6 & 98.7 & 96.6 & 95.4 & 93.4 \\
\hline & 8 & 98.4 & 95.8 & 94.7 & 92.4 \\
\hline & 10 & 96.1 & 94.5 & 93.5 & 89.4 \\
\hline \multirow{4}{*}{300} & 4 & 97.2 & 97.2 & 96.9 & 95.8 \\
\hline & 6 & 96.9 & 98.2 & 96.4 & 94.0 \\
\hline & 8 & 96.7 & 97.4 & 96.0 & 93.2 \\
\hline & 10 & 96.2 & 96.5 & 94.5 & 90.0 \\
\hline \multirow{4}{*}{350} & 4 & 96.6 & 97.2 & 97.6 & 97.4 \\
\hline & 6 & 94.9 & 97.0 & 97.4 & 97.0 \\
\hline & 8 & 94.0 & 96.7 & 97.0 & 96.6 \\
\hline & 10 & 91.5 & 95.5 & 96.7 & 95.8 \\
\hline \multirow{4}{*}{400} & 4 & 97 & 97.3 & 98.0 & 98.2 \\
\hline & 6 & 95.8 & 96.7 & 97.5 & 97.7 \\
\hline & 8 & 95.0 & 96.5 & 96.9 & 97.5 \\
\hline & 10 & 93.3 & 95.2 & 96.0 & 97.0 \\
\hline
\end{tabular}

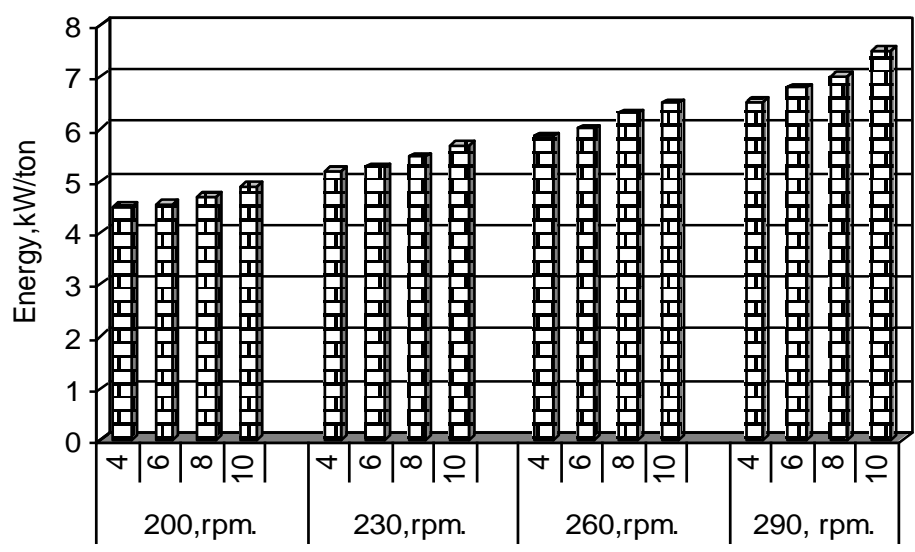

Air speed,m/s\& Sieve oscillation,rpm.

Fig. 7: Effect of cleaning air speed and sieve oscillation on consumed energy. 


\section{Effect of cleaning air speed sieve oscillation and feed rate on criterion cost requirements:}

The criterion cost is highly affected by seed losses and its price. The effect of parameter on cost was shown in Fig. 8. The data showed that the lowest production cost of $265.4 \mathrm{LE} /$ ton was recorded under parameter of air speed of 4 and $6 \mathrm{~m} / \mathrm{s}$, sieve oscillation $200 \mathrm{rpm}$ and feed rate $250 \mathrm{~kg} / \mathrm{h}$. Furthermore, the lowest vales of production cost were appear under used feed rate 300, 350 and $400 \mathrm{~kg} / \mathrm{h}$ with sieve oscillation 230, 260 and 290 rpm this was farther to decrease the seed losses amount.

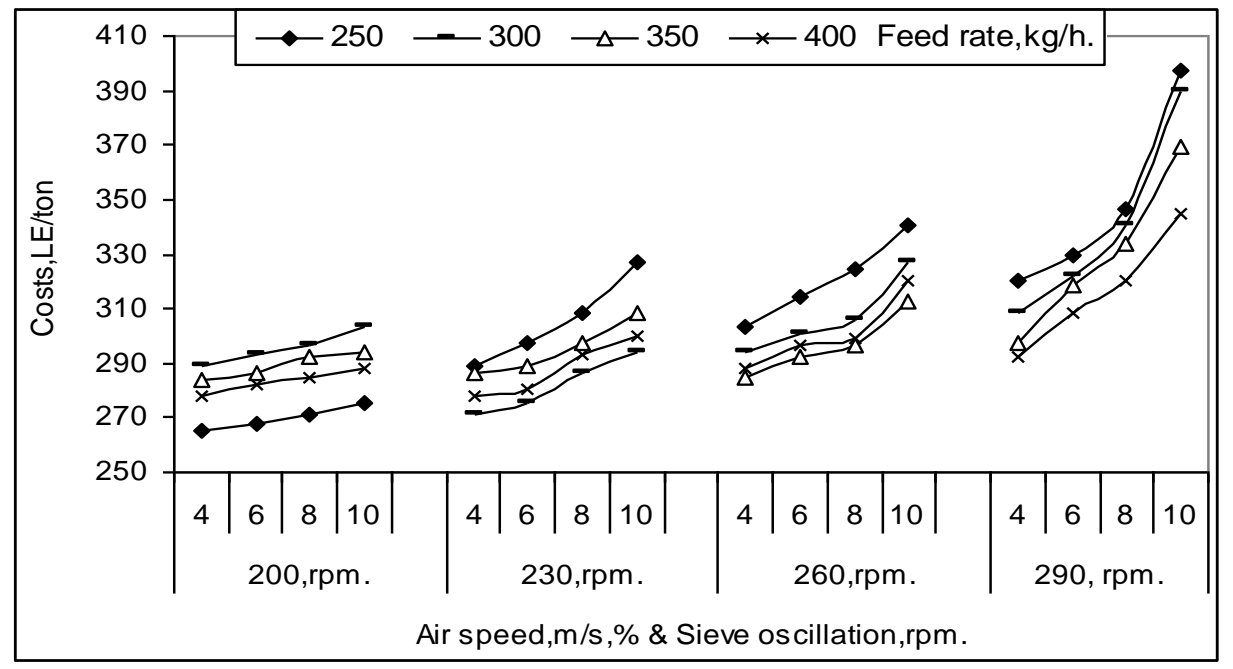

Fig.8: Effect of cleaning air speed, sieve oscillation and feed rate on criterion cost requirements.

\section{CONCULSION}

The obtained results from this investigation can be concluded as follows:

The lowest values of seed losses of 2.0, 3.0 and $8.0 \%$ were obtained at air speed of 4,6 and $8 \mathrm{~m} / \mathrm{s}$, feed rate of $250 \mathrm{~kg} / \mathrm{h}$ and moisture content $10 \%$. The minimum value of seeds damage 1.5 and $2.0 \%$ was noticed under feed rate of $250 \mathrm{~kg} / \mathrm{h}$, moisture content of 8 and10 $\%$ and air speed of $4 \mathrm{~m} / \mathrm{s}$. the maximum value of seeds purity of $98 \%$ was noticed under used feed rate of $250 \mathrm{~kg} / \mathrm{h}$, moisture content of $10 \%$ and air speed of 6,8 and10 m/s. the maximum value of seeds purity of 98.1, 98.2, 98.3and $98.4 \%$ was noticed under used feed rate of $250 \mathrm{~kg} / \mathrm{h}$, sieve oscillations of 200, 230, 260 and 290 
$\mathrm{rpm}$ and air speeds of $6 \mathrm{~m} / \mathrm{s}$ and moisture content of $10 \%$. The minimum value of seeds losses of $1.5 \%$ was noticed under used feed rate of $250 \mathrm{~kg} / \mathrm{h}$, sieve oscillations of 200rpm and air speed of 4 and $6 \mathrm{~m} / \mathrm{s}$. The maximum value of machine efficiency was noticed under used sieves oscillation of 200 $\mathrm{rpm}$ with feed rate of $250 \mathrm{~kg} / \mathrm{h}$ and cleaning air speed 4 and $6 \mathrm{~m} / \mathrm{s}$. The minimum energy consumed of $4.5 \mathrm{~kW} /$ ton was obtained by using cleaning air speed $4 \mathrm{~m} / \mathrm{s}$ and sieve oscillation $200 \mathrm{rpm}$. The lowest cost of 265.4 LE/ton was recorded under parameter of air speed of 4 and $6 \mathrm{~m} / \mathrm{s}$, sieve oscillation $200 \mathrm{rpm}$ and feed rate $250 \mathrm{~kg} / \mathrm{h}$.

\section{REFERENCES}

1. Amin, E. E. A. 2003: Effect of some physical and mechanical properties on grading efficiency, the 11th Annual Conference of Misr Society of Agr. Eng. 451-470.

2. Baryeh E.A and Mangope BK. 2002: Some physical properties of pigeon pea. J. Food Eng., 56: 59-65.

3. Mehdi G. V., H.Mobli, A. Jafari and S. Rafiee. 2007: Some engineering properties of paddy. Int. J. Agri. Biol., Vol. 9, No. 5, $1560-8530$.

4. Srivastava, A. K., Goering, C. E., Rohrbach, R. P., \& Buckmaster, D. R. 2006c: Chapter 6: Precision agriculture. In Engineering Principles of Agricultural Machines (pp. 123-138). St. Joseph,Mich.: ASABE. http://dx.doi.org/10.13031/2013.414685.

5. Shreen, F. A. M. and khaffaf, A. A. Kh. 2015: Physical and mechanical properties of some weed seeds which associated with Egyptian alfalfa seeds (Clover dodder and Chicory) Egypt.J. Agric. Res., 93 (5) (B).

6. Werby R. A. 2010: Performance cleaning unit for clover seeds affecting some physical and mechanical properties. Misr J. Ag. Eng., 27(1): 266- 283. (5, 7, 9 and 11mm) 


\section{الملخص العربى}

\section{استخدام مضرب تبيضض الارز فى فصل بذور حشائش البرسيم}

جمال حسن السيد" - شرين فؤاد عبدالحميا محمد** - يسرى عبد القوى شعبان ***

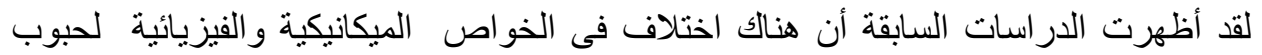
للبرسيم والحشائش التى تنمو معة وخاصة بذور الحامول والسريس، وهما من أكثر الحشائش

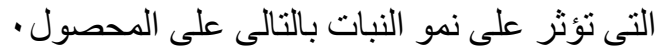

ونظر الزيادة معدلات تشغيل آلة الدر اس الثابثة واستخدامها فى دراس وفصل البذور عن التبن فى كثير من المحاصبل مثل القمح والبرسيم والمحاصيل البقولية وقد هيئة الآلة لآداء تللك

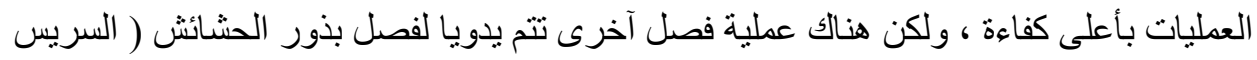
و الحامول) عن بذور البرسيم

لذلك تم تهيئة مضرب الارز لإستخدامة فى عملية الفصل تلك ، عن طريق زيادة الخلوص بين

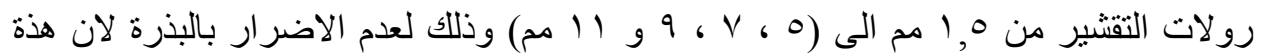

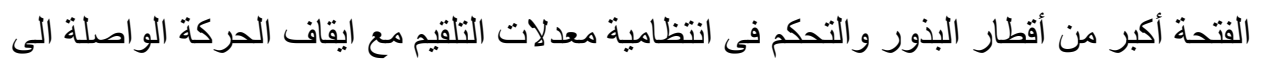
رولات التبيض .

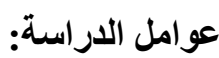

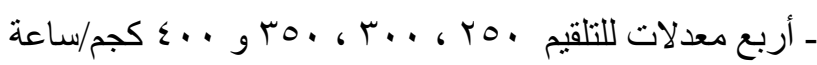

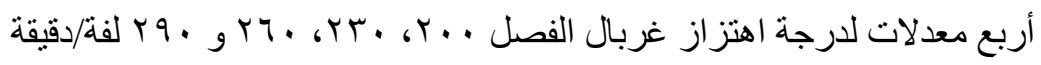

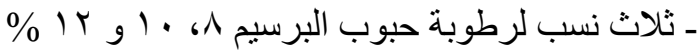

$$
\begin{aligned}
& \text { ـ أربع سر عات لهو اء التنظيف ع، 7، 1 و و • 1 م/ث }
\end{aligned}
$$

وتم تقييم تلكك العو امل من خلال در اسة معدل فقد الحبوب مع نواتج الفصل لهو اء التنظيف و أسفل تهل تهل

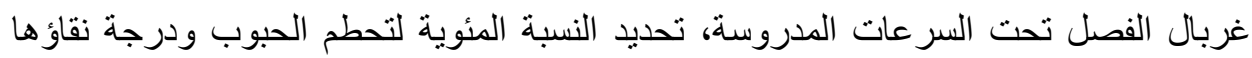
وكفاءة الآلة تحت معاملات الدراسة ، حساب الطاقة المستهلكة وتكاليف الفصل.

$$
\text { وكاتت نتائج الاراسة كالتالى }
$$

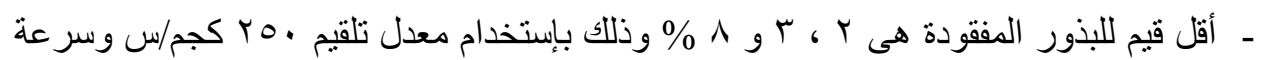

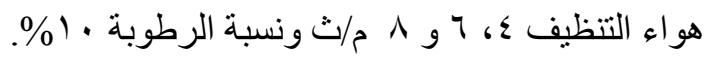

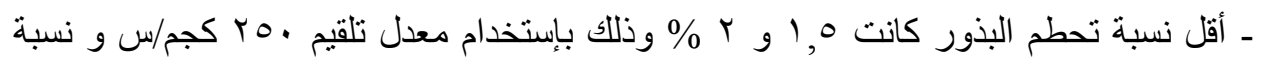

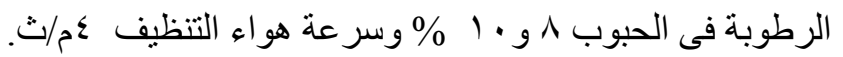

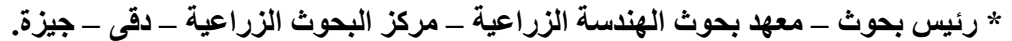

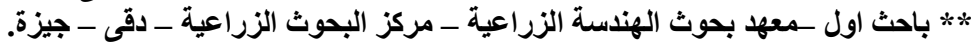

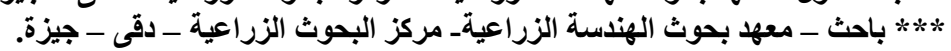




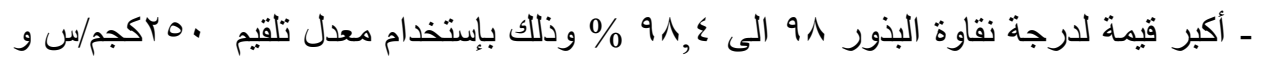

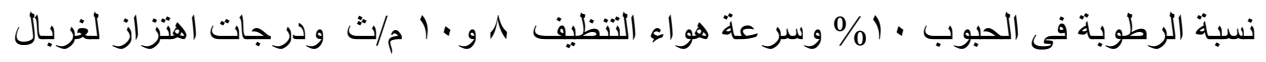

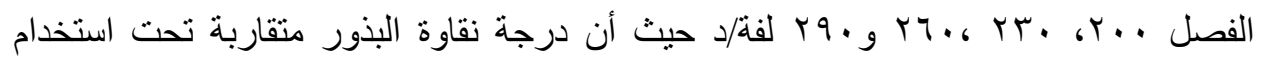

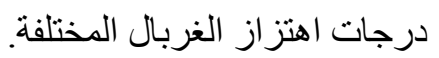

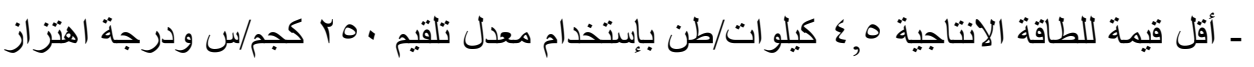

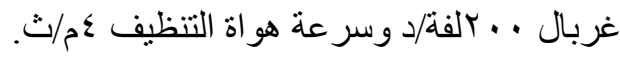

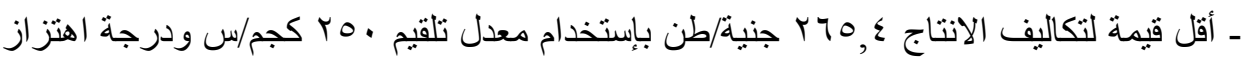

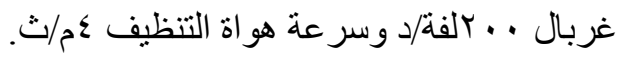

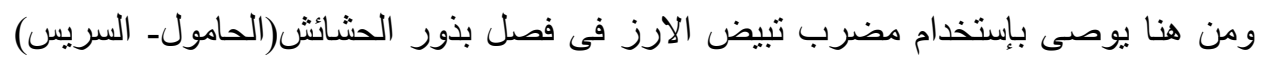

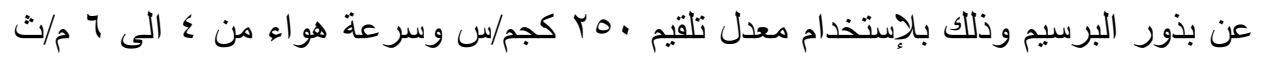

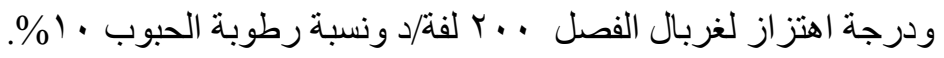

